\title{
DEVELOPING FRAMEWORK FOR IMPROVING DISASTER RESILIENCE IN URBAN SLUM UPGRADING
}

\section{Fahmyddin A'raaf Tauhid ${ }^{1 *}$ \\ ${ }^{1}$ Department of Architecture, Alauddin State Islamic University, Makassar e-mail: *1 fahmyddin.tauhid@uin-alauddin.ac.id}

\begin{abstract}
Disaster resilience has become an important urban agenda due to the increasing disaster intensity and massive impacts. Developing framework for measuring disaster resilience is a critical policy particularly for urban slum area. It requires extensive and comprehensive approach to achieve sustainable measurement. Providing the integration of the research and the present disaster resilience measurement through content analysis of qualitative approach, this study introduces the framework composed of categories and indicators for improving disaster Resilience in urban slum areas under upgrading efforts. It recommends that community capital: the public infrastructure and facilities, human, financial, natural, and social can be categories for indicators development. These capitals can reflect numerous elements, resources, and relationships within an urban slum areas and its main contribution for community.
\end{abstract}

Keywords: Disaster Resilience; Slum Upgrading; Community Capital.

\footnotetext{
${ }^{1}$ Department of Architecture, Alauddin State Islamic University, Makassar
} 


\section{INTRODUCTION}

The growth of urban area has become one of the most important issue and phenomena of the 21st century. Managing cities have challenged the policy makers and government with more complex problems and limited resources. In 2014about 1 billion people live in slums concentrating in less developed countries accounting for about $30 \%$ of respective urban population (United Nations, 2015). This proportion is expected to increase to $66 \%$ or about three billion by 2050 with close to 90 percent of the increase concentrated in Asia and Africa (UN-DESA, 2014). For instance, in India, $31 \%$ of the population lives in urban areas and $17 \%$ of the urban population (65 million people) lives in slums (Census of India, 2011). However, the issue faced by cities would be dissimilar since three-quarters of the current urban population lives in low- and middle-income nations (IPCC, 2014). Rapid urbanization, uncontrolled and unplanned growth combined with limited government capacity and resources has led to the expansion of informal, heavily overpopulated settlements and slums.

Slums have been a main part of cities since the time of city to describe people living under substandard conditions and squalor. UN-Habitat (2003) describes slums as area that are characterized by limited access to safe drinking water and sanitation, insecure tenure, non-durable buildings and overcrowding. Cities (2006) also defines slums as 'neglected parts of cities where housing and living conditions are appallingly poor'. The lack of basic infrastructure services including housing, water and sanitation services have worsened the life condition of informal settler. Nevertheless, this study argues that improving the slum condition might provide the opportunities to path the way for sustainability and improving disaster resilience as well as restoring environment. It can be contended that urban slums development are greatly influenced by the incompetence of local governments to plan and provide affordable housing for the lowincome groups.

This study argues that the lack of coordination among authorities at the city and national level is the main issue. The incoordination range from economic development, urban planning, to land allocation. Slum comprises a wide range of informal settlements form such as squatter, shanty town, favela etc. that presently exemplify poverty in developing countries cities. Despite their difference of definition, these informal settlement represent deprived communities continuing to have great impact on the urban physical and economic.

As slum may bring negative social, economy and environmental consequences, local authorities usually respond by carried out demolition and slum upgrading to improve the conditions. Yet, since demolition have been criticized for unsustainable approach (Fontein, 2009), slum upgrading has been considered as a more sustainable method to handling slum (Cirolia, Gorgens, Van Donk, Smit, \& Drimie, 2016). The slum upgrading have become an important approach adopted by city or local authorities and international aid organizations. Slum upgrading is a fundamental right for people to live with basic dignity and in satisfactory conditions. According to Cities (2018), cities may benefit from fostering inclusion, promoting economic development, addressing overall city issues, improving quality of life, to providing shelter for the poor. There are many factor that required for successful slum upgrading efforts. However, two most important are strong political will of government and communities participation that prioritizing in financing, institutions and regulations Cities (2018). The successful slum upgrading projects would depend on the aims of respective initiatives. For instance, in Indonesian national slum upgrading project, the initiatives are aimed to reduce infrastructure gap, provide urban services (water, sanitation, and access to housing), end extreme poverty and promote shared prosperity (World Bank 2016).

Slum upgrading goal would be effective when integrated with other program for instance poverty alleviation, health and education, environmental and sanitation improvement, public infrastructure and transportation expansion. Moreover, as natural disaster in developing countries increase, the initiative to improve disaster resilience have attracted city government, academics 
and international organization for extensively discussion, in particular of vulnerable poor group in slums area Dodman, Hardoy, and Satterthwaite (2008); Tauhid \& Zawani (2018).

The resilience idea has been adopted by many international organization, city management and policy makers since the Hyogo Frame work for Action (HFA) in 2005. Despite diverse concepts of resilience, this paper uses Béné's study (2013) that defines it as "any capacity and skills, and action, strategy, investment and anticipation, which helps individual(s), households and communities to anticipate, absorb, accommodate, or recover from the impacts of a particular adverse event (shock, stress, or(un)expected changes)". This definition approach would allow this study to examine diverse research units at a city scale dimension.

This study believes that slum upgrading provides an opportunity for cities to improve community disaster resilience especially for poor group as such areas have limited resource, high density housing, lack of land tenure, contested social power structures and marginalized community. The question is how to develop a framework that composing of categories and indicators for improving community disaster resilience within urban slum upgrading initiatives. This paper argues that a frame work must be generic enough to be able to compare different communities in same context of slum. Based on Levine's study, developing a framework to measure community resilience can use five approaches that based on functionality, indicators and characteristics, food access, activities, and theoretical resilience frameworks. Developing framework based on theoretical resilience combined with categorization and indicators is gaining the most traction within the scholars and international aid organization. Therefore, this paper aims to introduce a framework for improving disaster resilience in urban slum areas through categories and indicators.

\section{METHOD}

This study have drawn on the work of Community Based Resilience Analysis (CoBRA) by UNDP Drylands Development Centre to conduct extensive research into disaster resilience assessment methods. Using qualitative content analysis, it combined CoBRA approach with numerous respected bodies of disaster resilience works including Arbon et al (2016), Woolf et al (2016), Patel et al. (2018), Aßheuer, Thiele-Eich, and Braun (2013) and Miles (2015)to create a list of the characteristics of a disaster resilient community in urban slum area. The respective list represents the data of abstraction process that would be reduced to concepts. This list composed of categories describing the research phenomenon as a prerequisite for successful content analysis (Elo \& Kyngäs, n.d.); (Morgan, 1993).

The abstraction process also partially depends on the researcher's insight and intuitive action. From the perspective of validity, this study describes how the results were created (Kvale, 1989). This study used deductive content analysis approach involving three phases: preparation, organization, and reporting of results. The organization phase involves categorization matrix development, whereby all the literature data are reviewed for content to identify relevant categories and indicators. In the reporting phase of study, outcomes are described by the content of the categories and indicators describing the framework. Using community capital the basis for developing framework, this study would cover various elements, resources, and relationships within a slum community and their significance.

\section{FINDINGS AND DISCUSSIONS}

The quantitative measurement of resilience has been contested in recent literature discussion. On the one hand some academics views that disaster resilience cannot be operationalized into quantitative approach, while on the one side argues that quantification is vital 
as a diagnostic tool for assessing interventions such as slum upgrading in communities and cities (Jülich 2018; Shabrina et al. 2018; Mayunga 2009; Asadzadeh et al (2017). Developing a generic framework to measure resilience faces several functioning challenges of the multi-scalar and multidimensional nature of resilience.

Levine (2014) contended that existed frameworks to implement resilience projects have made little attempt to quantify the impact of program. Study of Arup International Development (2011) also concluded that any framework to measure urban community resilience need to use a vast number of variables that draw on a wide range of networking systems within at city level. Nevertheless, it would be problematic to use a large number of variables in developing framework for disaster resilience measurement. Much of the framework on resilience has been conducted for national, subnational, an individual or household level. The framework for resilience on slumdwellers commonly used household level as basis for measurement. Hence, this paper proposed framework specifically targets this urban poor group in slum area at household or community level.

Using study of framework on disaster resilience from CoBRA approach with several respected disaster resilience studies; Arbon et al (2016), Woolf et al (2016), Patel et al. (2018), Aßheuer et al (2013) and Miles, S. B. (2015), this study introduces such framework that holistically consider resilience across time frames and locational contexts. It applies community capital: the public infrastructure and facilities, human, financial, natural, and social from which a community particularly in slum area receives benefits and on which people rely for life as the basis for developing framework. The community capitals approach allow this development to view the various elements, resources, and relationships within a slum community and their significance to the overall functioning of the slum areas and its community. This paper identifies the categories and proposed indicators of a framework for measuring resilience in slum area as can be seen in table 1.

Table 1. The categories and proposed indicators of a framework for measuring resilience in slum area

Pategories
Proposed Indicators

Public Infrastructure and facilities Availability of: roads, water networks, electricity, telecoms, street paving, street lighting, waste and garbage facilities, public space, health centers or clinics, communal amenities, education facilities, public schools.

Human level of education, years of formal education, vocational education and training, practical skills, ability to work, age group, knowledge and experience obtained from awareness program and dealing with disasters

Financial

Natural household income, household savings, pensions and remittances, property value, employment, and investments Amount of owned and access to land, access to water for production and life, water quality, air quality, soil quality, land quantity and quality, public space quantity and quality

Social The formal (membership) or informal participation in groups, social relations, networks, and access to wider institutions in a community

Public infrastructure and facilities, human, financial, natural and social capital as categories for developing disaster resilience measurement are closely interlinked. A number of studies revealed a robust correlation between human and financial capital (Saba et al., 2012; Santos- 
Rodrigues et al., 2013). Our study argues also that if community or individual invests more in human capital means better education and trainings then it will in turn be getting to improve disaster resilience.

The study of Islam and Walkerden (2014) also concludes that the human capital has a positive correlation with physical capital. This study argues that households with higher levels of human capital were likely to have higher levels of physical capital such as in slum area.

According to Ottósson and Klyver (2010), human capital and social capital were found a positive and significant relationship meaning that increasing human capital increases the status of social capital concurrently. Lastly, a number of studies also conclude an insignificant relationship between human and natural capital Behbudi, Mamipour, and Karami (2010), Philippot (2010).

\section{CONCLUSION}

In recent years, various study and program have been undertaken by scholars and related parties to develop framework for measuring disaster resilience more comprehensive. Conversely, there is a few study to study such framework for measurement in the context of urban slum area. It remains important to note that community living in such area is one of the most vulnerable community to disaster due to lack of capital they have.

Designing a generic framework to measure disaster resilience in respective urban slum require comprehensive, the multi-scalar and multi-dimensional nature of resilience approach. Therefore this study provides an introduction of disaster resilience measurement at developing and applying frameworks in urban area under slum upgrading interventions. In addition, it attempts to identify community capital from academic and projects works that have already been studied. This study concludes that community capital: the public infrastructure and facilities, human, financial, natural, and social can be categories for the indicators development. These capitals can reflect numerous elements, resources, and relationships within an urban slum areas and its main contribution for community.

To conclude, this framework reveals that enhanced study need to be undertaken by various urban stakeholders particularly urban poor group in slum area to address problem at micro-level of a community. This issue, that require to be further identified in future research to produce more sustainable disaster resilience measurement at urban slum area context and level. 


\section{REFERENCES}

Arbon, P., Steenkamp, M., Cornell, V., Cusack, L., \& Gebbie, K. (2016). Measuring disaster resilience in communities and households. International Journal of Disaster Resilience in the Built Environment, 7(2), 201-215. https://doi.org/10.1108/ijdrbe-03-2015-0008

Arup International Development. (2011). Characteristics of a Safe and Resilient Community: Community Based Disaster Risk Reduction Study. Geneva.

Asadzadeh, A., Kötter, T., Salehi, P., \& Birkmann, J. (2017). Operationalizing a concept: The systematic review of composite indicator building for measuring community disaster resilience. International Journal of Disaster Risk Reduction, 25(1), 147-162. https://doi.org/10.1016/j.ijdrr.2017.09.015

Aßheuer, T., Thiele-Eich, I., \& Braun, B. (2013). Coping with the impacts of severe flood events in Dhaka's slums - the role of social capital. Erdkunde, 67(1), 21-35. https://doi.org/10.3112/erdkunde.2013.01.03

Behbudi, D., Mamipour, S., \& Karami, A. (2010). Natural resource abundance, human capital and economic growth in the petroleum exporting countries. Journal of Economic Development., 35(1), 81-102.

Cirolia, L. R., Gorgens, T., Van Donk, M., Smit, W., \& Drimie, S. (2016). Upgrading informal Press., Settlements in South Africa: A Partnership-Based Approach. Cape Town: UCT Press.

Cities, A. (2006). Cities Alliance for Cities Without Slums: Action plan for moving slum upgrading to scale.Cities Alliance. Washington, DC. Diambil dari http://www.citiesalliance.org/sites/citiesalliance.org/files/ActionPlan.pdf.

Cities, A. (2018). About Slum Upgrading. Diambil dari https://www.citiesalliance.org/aboutslum-upgrading\#Why_is_slum_upgrading_important

Dodman, D., Hardoy, D., \& Satterthwaite. (2008). Urban Development and Intensive and Extensive Risks, Background paper to Global Assessment Report 2009. Geneva: UNISDR.

Elo, S., \& Kyngäs, H. (n.d.). The Qualitative Content Analysis Process. 2008, 62(1), 107-115.

Fontein, J. (2009). Anticipating the Tsunami: Rumours, Planning and the Arbitrary State in Africa. Zimbabwe, 79(3), 369-398.

Islam, R., \& Walkerden, G. (2014). How Bonding and Bridging Networks Contribute to Disaster Resilience and Recovery on the Bangladeshi Coast. International Journal of Disaster Risk Reduction, 10(2), 281-291.

Kvale, S. (1989). Issues of Validity in Qualitative Research.

Levine, S. (2014). Assessing Resilience : Why Quantification Misses the Point. London: Overseas Development Institute.

Miles, S. B. (2015). Foundations of Community Disaster Resilience: Well-Being, Identity, Services, and Capitals. Environmental Hazards, 14(2), 103-121. https://doi.org/10.1080/17477891.2014.999018

Morgan, D. . (1993). Qualitative Content Analysis: A Guide to Paths not Taken. Qualitative Health Research, 1, 112-121.

Ottósson, H., \& Klyver, K. (2010). The Effect of Human Capital on Social Capital Among Entrepreneurs. Journal of Enterprising Culture, 18(4), 399-417.

Tauhid, F. A., \& Zawani, H. (2018). Mitigating Climate Change Related Floods in Urban Poor Areas: Green Infrastructure Approach. Journal of Regional and City Planning, 29(2), 98112. https://doi.org/10.5614\%2Fjrcp.2018.29.2.2 